\title{
MicroRNA-27a protects retinal pigment epithelial cells under high glucose conditions by targeting TLR4
}

\author{
XIAOLEI TANG, YAN DAI, XIAOLI WANG, JIAN ZENG and GUIRONG LI \\ Department of Ophthalmology, Mianyang Central Hospital, Mianyang, Sichuan 621000, P.R. China
}

Received June 1, 2016; Accepted April 21, 2017

DOI: $10.3892 /$ etm.2018.6150

\begin{abstract}
The present study aimed to investigate whether microRNA-27a (miRNA27a) is associated with the pathogenesis of diabetic retinopathy, and to elucidate the underlying molecular mechanism of any potential association. In retinal pigment epithelial (RPE) cells treated with high glucose, miRNA27a expression, determined by reverse transcription-quantitative polymerase chain reaction analysis, was decreased. Caspase-3/9 activity and B-cell lymphoma 2-associated X (Bax) protein expression was increased in RPE cells subjected to high glucose. Inhibition of miRNA27a suppressed the viability, and increased the caspase-3/9 activity and Bax protein expression of RPE cells treated with high glucose. Inhibition of miRNA27a expression also increased the expression of interleukin (IL)- 6 , IL-1 $\beta$, tumor necrosis factor (TNF)- $\alpha$ and Toll-like receptor 4 (TLR4) in RPE cells treated with high glucose. Treatment with immunostimulatory (is)RNA directed against TLR4 was observed to inhibit caspase-3/9 activity, decrease the expression of TLR4, Bax, IL-6, IL-1 $\beta$ and TNF- $\alpha$, and increase the viability of RPE cells subjected to high glucose following the inhibition miRNA27a. In conclusion, the results of the present study suggest that miRNA27a protects RPE cells subjected to high glucose via inhibiting inflammation and apoptosis through targeting TLR4.
\end{abstract}

\section{Introduction}

Due to improvements in living standards, the number of patients with type 2 diabetes has been increasing; in 1990 $3.8 / 100,000$ individuals were diabetic, however in 2010 $4.9 / 100,000$ were diabetic $(1,2)$. According to a survey released by The New England Journal of Medicine in March 2014, the morbidity rate of individuals aged $>20$ years old with diabetes in China was $\sim 9.1 \%$ (2). In addition, 140 million individuals

Correspondence to: Dr Yan Dai, Department of Ophthalmology, Mianyang Central Hospital, 12 Changjia Alley, Mianyang, Sichuan 621000, P.R. China

E-mail: daoyuxialie8@126.com

Key words: microRNA-27a, retinal pigment epithelial cells, Toll-like receptor 4, inflammation, apoptosis are classed as pre-diabetic patients in China (3). Diabetic retinopathy (DR) is one of the primary microvascular complications of diabetes and the majority of patients with diabetes suffer from a certain level of DR (4). Previous studies have demonstrated that the morbidity rate of DR is high and leads to severely impaired eyesight $(1,4)$. In order to inhibit the progression of diabetes, it is essential to diagnose the condition early and control blood glucose levels. There is currently no cure for DR; therefore, further studies investigating the pathogenesis of DR are required (1).

As a small single-stranded RNA molecule with a length of 21-25 nucleotides, microRNA (miRNA) participates in regulating molecular growth, differentiation, proliferation and apoptosis. miRNA binds to target mRNA molecules through complementary base paring (5). Increasing amounts of evidence demonstrates that miRNA serves an important role in regulating diabetes and its complications (5). Furthermore, miRNA regulates DR through a number of biological signaling pathways, including phosphatidylinositol 3-kinase/RAC-alpha serine/threonine-protein kinase, transforming growth factor $\beta-1$ and Wnt (6).

DR is a disease that may lead to blindness in individuals between 20 and 70 years of age, and is therefore an important area of research (7). A number of previous studies have suggested that different pro-inflammatory factors participate in the occurrence and progression of DR $(8,9)$. This provides novel directions for future research investigating the pathogenesis of DR and for potential treatments for DR using anticytokine agents.

Diabetes is a chronic metabolic disease characterized by hyperglycemia resulting from defects in insulin production or insulin resistance, and is associated with a high morbidity rate and a number of complications (7). Previous studies have revealed that type 1 and 2 diabetes present as mild systemic inflammation, resulting from the production and secretion of proinflammatory cytokines following the stimulation of innate immune cells by endogenous and exogenous ligands $(10,11)$. For example, free fatty acids and glycosylated terminal products induce an increase in leukocyte adhesion molecules, proinflammatory cytokines and haemopoietic factors by combining with Toll-like receptors (TLRs) to activate nuclear factor (NF)- $\kappa \mathrm{B}$-associated signaling pathways (12). As a state of mild systemic inflammation, diabetes is characterized by an increase in numerous proinflammatory cytokines, including tumor necrosis factor 
(TNF)- $\alpha$, interleukin (IL)-6, IL-1 $\beta$, C-reactive protein, plasminogen activator inhibitor-1 and adiponectin (13).

\section{Materials and methods}

Cell culture. Human retinal pigment epithelial (RPE)-1 cells were purchased from The Cell Bank of Type Culture Collection of Chinese Academy of Sciences (Shanghai, China) and maintained in Dulbecco's modified Eagle's medium: Nutrient Mixture F-12 (DMEM-F12) supplemented with $10 \%$ fetal bovine serum, 100 units $/ \mathrm{ml}$ penicillin and $100 \mu \mathrm{g} / \mathrm{ml}$ streptomycin (all Gibco; Thermo Fisher Scientific, Inc., Waltham, MA, USA) in a tissue culture incubator at $37^{\circ} \mathrm{C}$ with $5 \% \mathrm{CO}_{2}$.

Cell viability assay. Cell viability was determined using MTT reagent (Invitrogen; Thermo Fisher Scientific, Inc.). RPE-1 cells $\left(1 \times 10^{3} \mathrm{cell} / \mathrm{ml}\right)$ were incubated with different doses of glucose $(0,1,5,10,20,50$ and $100 \mathrm{mM}$; Guoyao Group Chemical Reagent Co., Ltd., Shanghai, China) in DMEM-F12 for 12 or $24 \mathrm{~h}$ at $4^{\circ} \mathrm{C}$. Subsequently, $0.5 \mathrm{mg} / \mathrm{ml}$ MTT solution was added and the cells were incubated for $4 \mathrm{~h}$ at $37^{\circ} \mathrm{C}$. Then, the supernatants were removed and dimethyl sulfoxide was added for $20 \mathrm{~min}$ at $37^{\circ} \mathrm{C}$. Cell viability was measured at $490 \mathrm{~nm}$ using a microplate reader (Multiskan ${ }^{\circledR} \mathrm{EX}$; Thermo Fisher Scientific, Inc.).

miRNA reverse transcription-quantitative polymerase chain reaction $(R T-q P C R)$ analysis. Total RNA was extracted from RPE-1 cells using the TRIzol ${ }^{\mathrm{TM}}$ reagent (Invitrogen; Thermo Fisher Scientific, Inc.) according to the manufacturer's protocol. Total RNA was reverse-transcribed into cDNA using the PrimeScript ${ }^{\circledR}$ RT Master Mix (Perfect Real Time) assay kit (Takara Bio, Inc., Shiga, Japan) according to the manufacturer's protocol. RT-qPCR was performed using a SYBR $^{\circledR}$ Premix Ex Taq ${ }^{\text {TM }}$ kit (Takara Bio, Inc.) according to the manufacturer's protocol. qPCR was completed using $500 \mathrm{ng}$ of cDNA and the SYBR-Green Real-Time PCR Master mix (Applied Biosystems; Thermo Fisher Scientific, Inc.). The thermocycling conditions for PCR included a total of 40 cycles as follows: $5 \mathrm{~min}$ at $95^{\circ} \mathrm{C} ; 30 \mathrm{sec}$ at $95^{\circ} \mathrm{C} ; 60 \mathrm{sec}$ at $30^{\circ} \mathrm{C}$; and $30 \mathrm{~min}$ at $72^{\circ} \mathrm{C}$. The following primer sequences were used: miRNA27a forward, 5'-ACAGGCTAGCGC CGCCTAAC-3' and reverse, 5'-CCTTAAGGCCCAAGA TTACG-3'; and U6 forward, 5'-TCGCTTCGGCAGCAC ATATAC-3' and reverse 5'-TATGGAACGCTTCACGAA TTTG-3'. Expression levels were quantified using the $2^{-\Delta \Delta C q}$ method (14).

Small interfering (si)RNA and immunostimulatory (is)RNA transfection. The sequences of siRNA directed against miRNA27a (si-miRNA27a; GenePharma Co., Ltd., Shanghai, China) were as follows: Sense, 5'-GCGGAACUUAGCCAC UGUGAA-3' and antisense, 5'-CAGUACUUUUGUGUA GUACAA-3'. The sequences of isRNA directed against TLR4 (isRNA-TLR4; GenePharma Co., Ltd.) were as follows: Sense, 5'-GGACUUGAAAGACCUUGGATT-3' and antisense, 5'-UCCAAGGUCUUUCAAGUCCTC-3'. RPE-1 cells $\left(1 \times 10^{5} \mathrm{cell} / \mathrm{ml}\right)$ were transfected with $200 \mathrm{ng}$ of si-miRNA27a and/or isRNA-TLR4 using a Lipofectamine ${ }^{\circledR} 2000$ reagent
(Invitrogen; Thermo Fisher Scientific, Inc.) according to the manufacturer's protocol. Transfected RPE cells were incubated with glucose for $24 \mathrm{~h}$ prior to subsequent assays.

Caspase-3/9 activity assay. A total of $1 \times 10^{6}$ transfected RPE-1 cells were washed with ice-cold PBS and protein extracted using radioimmunoprecipitation assay (RIPA) buffer (Promega Corporation, Madison, WI, USA). The amount of total protein was quantified using a BCA Protein assay kit (Pierce Biotechnology; Thermo Fisher Scientific, Inc.). Total protein $(20 \mu \mathrm{g})$ was incubated with Ac-DEVD-pNA and Ac-LEHD-pNA (both Beyotime Institute of Biotechnology, Haimen, China) for $1 \mathrm{~h}$ at $37^{\circ} \mathrm{C}$, substrates for Caspase-3 and 9, respectively. Caspase-3/9 activity was subsequently measured at $405 \mathrm{~nm}$ using a microplate reader (Multiskan EX).

Western blot analysis. Transfected RPE cells were washed with ice-cold PBS and protein extracted using RIPA buffer. The amount of total protein was quantified using a BCA Protein assay kit (Pierce Biotechnology; Thermo Fisher Scientific, Inc.). Total protein $(50 \mu \mathrm{g})$ was separated by $8-12 \%$ SDS-PAGE and transferred onto a nitrocellulose membrane (Bio-Rad Laboratories, Inc., Hercules, CA, USA). The membrane was blocked with 5\% skimmed milk-Tris-buffered saline-Tween-20 for $1 \mathrm{~h}$ at $37^{\circ} \mathrm{C}$. The membrane was then incubated with rabbit polyclonal primary antibodies directed against B-cell lymphoma 2-associated X protein (Bax; cat. no. sc-6236), TLR4 (cat. no. sc-10741) (both 1:500; Santa Cruz Biotechnology, Inc., Dallas, TX, USA) and GAPDH (cat. no. sc-25778; 1:2,000; Sigma-Aldrich; Merck KGaA, Darmstadt, Germany) overnight at $4^{\circ} \mathrm{C}$, followed by incubation with horseradish peroxidase-conjugated secondary antibodies (cat. no. sc-2004; 1:5,000; Santa Cruz Biotechnology, Inc.) for $2 \mathrm{~h}$ at room temperature. The blots were visualized using enhanced chemiluminescence reagent (Boster Biological Technology, Ltd., Wuhan, China) and analysed using Image Lab software (version 3.0; Bio-Rad Laboratories, Inc.).

ELISA to assess the expression of $I L-6, I L-1 \beta$ and TNF- $\alpha$. Transfected RPE-1 cells $\left(1 \times 10^{5}\right.$ cell $\left./ \mathrm{ml}\right)$ were washed with ice-cold PBS and centrifuged at $12,000 \mathrm{xg}$ for $15 \mathrm{~min}$ at $4{ }^{\circ} \mathrm{C}$. The expression of IL-6 (cat. no. D6050), IL-1 $\beta$ (cat. no. DLB50) and TNF- $\alpha$ (cat. no. DTA00C) in the cell culture supernatant were measured using ELISA kits (R\&D Systems Inc., Minneapolis, MN, USA) according to the manufacturer's protocol. The ELISA plates were then measured at $450 \mathrm{~nm}$ using a microplate reader (Multiskan ${ }^{\circledR} \mathrm{EX}$ ) to determine the expression of IL-6, IL-1 $\beta$ and TNF- $\alpha$.

Statistical analysis. Results are expressed as the mean \pm standard deviation. Two-tailed Student's t-tests were performed using SPSS 17.0 (SPSS, Inc., Chicago, IL, USA). P $<0.05$ was considered to indicate a statistically significant difference.

\section{Results}

Glucose suppresses RPE cell viability and $m R N A 27 a$ expression. In the current study, RPE cells were treated with a series of glucose concentrations $(0,1,5,10,20,50$ and $100 \mathrm{mM})$ for 12 or $24 \mathrm{~h}$, after which the expression of mRNA27a was 
measured. Glucose treatment was demonstrated to reduce the RPE cell viability in a dose- and time- dependent manner (Fig. 1A). Notably, $20 \mathrm{mM}$ glucose reduced the number of viable cells to $50 \%$ after $24 \mathrm{~h}$ (Fig. 1A). Glucose treatment also decreased the amount of miRNA27a in a dose-dependent manner for $24 \mathrm{~h}$ (Fig. 1B). A total of 20 and $50 \mathrm{mM}$ glucose was also able to significantly inhibit the expression of mRNA27a in RPE cells compared with the control $(0 \mathrm{mM}$ glucose $)(\mathrm{P}<0.01$; Fig. 1B).

Inhibition of miRNA-27a suppresses the viability of RPE cells under high glucose conditions. Due to the results of the initial experiment, $20 \mathrm{mM}$ glucose was selected as the high concentration of glucose and used in subsequent experiments. In addition to glucose treatment, miRNA27a was inhibited via the transfection of si-miRNA27a. The results of this assay indicated that the inhibition of miRNA27a and treatment with high glucose significantly inhibited the viability of RPE cells compared with the untransfected RPE cells cultured under high glucose conditions ( $\mathrm{P}<0.01$; Fig. 2).

Inhibition of mRNA27a increases caspase-3/9 activity, and Bax and TLR4 protein expression in RPE cells subjected to high glucose. The role of mRNA27a in regulating caspase-3/9 activity, Bax and TLR4 protein expression in RPE cells under high glucose conditions was assessed. Caspase-3/9 activity (Fig. 3A), and Bax and TLR4 protein expression (Fig. 3B-D) in RPE cells treated with high glucose significantly increased following the inhibition of miRNA27a compared with the group treated with high glucose alone $(\mathrm{P}<0.01 ;$ Fig. 3$)$.

Inhibition of mRNA27a increases IL-6, IL-1 $\beta$ and TNF- $\alpha$ expression in RPE cells subjected to high glucose. The expression of IL-6, IL-1 $\beta$ and TNF- $\alpha$ was measured in RPE cells transfected with si-miRNA27a and cultured under high glucose conditions using ELISAs. When compared with the untransfected RPE cells cultured with $20 \mathrm{mM}$ glucose, the expression of IL- 6, IL- $1 \beta$ and TNF- $\alpha$ was significantly increased in RPE cells treated with si-miRNA27a and high glucose $(\mathrm{P}<0.01$; Fig. 4).

TLR4 expression is inhibited in si-miRNA27a-transfected $R P E$ cells subjected to high glucose following the transfection of isRNA-TLR4. The present study assessed the effect of isRNA-TLR4 on the expression of TLR4 and Bax protein, and caspase-3/9 activity in RPE cells subjected to high glucose following the inhibition of mRNA27a. isRNA-TLR4 significantly suppressed the expression of TLR4 and Bax protein, and caspase-3/9 activity in RPE cells treated with high glucose and transfected with si-miRNA27a, compared with RPE cells treated with high glucose and transfected with si-miRNA27a $(\mathrm{P}<0.01$; Fig. 5).

Inhibition of TLR4 increases the viability of si-miRNA27a-transfected RPE cells subjected to high glucose. The effect of TLR4 on the viability of RPE cells subjected to high glucose following the inhibition of miRNA27a expression was investigated. Inhibition of TLR4 significantly increased the viability of si-miRNA27a-transfected RPE cells under high glucose conditions, compared with RPE cells
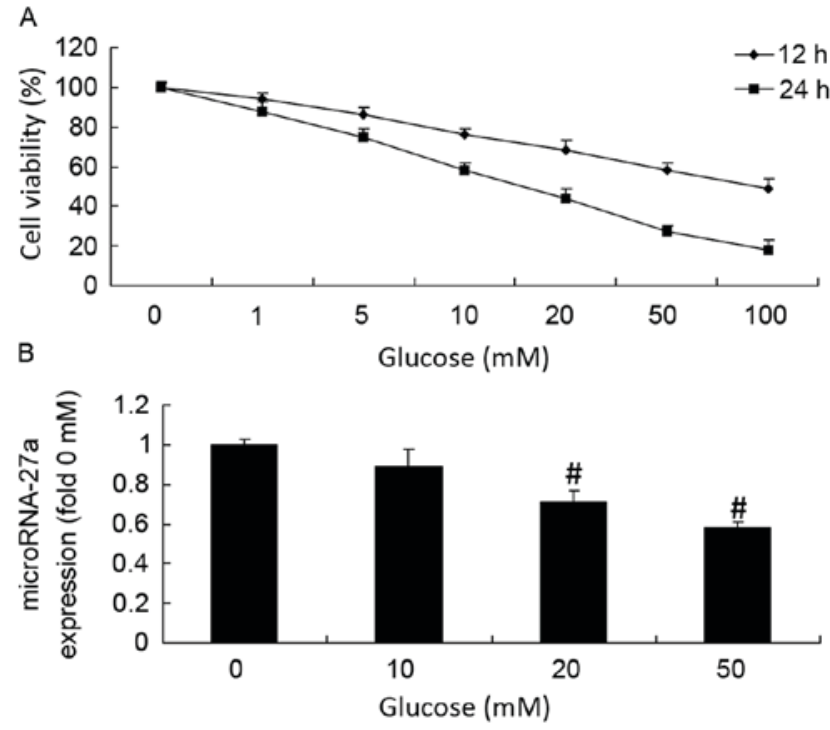

Figure 1. Glucose treatment decreases the viability and expression of microRNA-27a of RPE cells. The (A) viability and (B) microRNA-27a expression of RPE cells treated with glucose. ${ }^{\#} \mathrm{P}<0.01$ vs. $0 \mathrm{mM}$ group. RPE, retinal pigment epithelial.

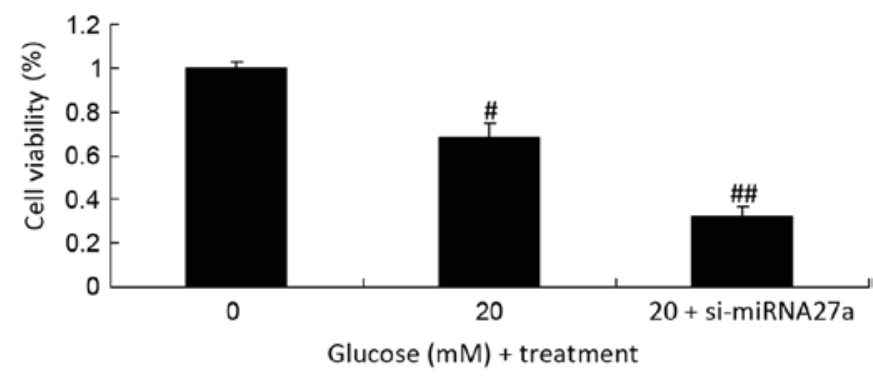

Figure 2. Inhibition of miRNA27a reduces the viability of retinal pigment epithelial cells under high glucose conditions. ${ }^{\#} \mathrm{P}<0.01$ vs. $0 \mathrm{mM}$ group; ${ }^{\# \#} \mathrm{P}<0.01$ vs. $20 \mathrm{mM}$ group. si, small interfering RNA; miRNA27a, microRNA-27a.

treated with high glucose and transfected with si-miRNA27a $(\mathrm{P}<0.01$; Fig. 6).

Inhibition of TLR4 decreases the expression of $I L-6, I L-1 \beta$ and TNF- $\alpha$ in miRNA27a-transfected RPE cells subjected to high glucose. To assess the effect of TLR4 inhibition on the expression of IL-6, IL- $1 \beta$ and TNF- $\alpha$ in RPE cells subjected to high glucose following the inhibition of miRNA-27a was investigated. The expression of IL-6, IL-1 $\beta$ and TNF- $\alpha$ in miRNA27a-transfected RPE cells subjected to high glucose was significantly suppressed following TLR4 inhibition, compared with RPE cells treated with high glucose and transfected with si-miRNA27a $(\mathrm{P}<0.01 ;$ Fig. 7).

\section{Discussion}

Diabetes is the third most frequently chronic non-infectious disease diagnosed globally, following tumors and cardiovascular/cerebrovascular diseases (1). In developed countries, DR is the primary cause of blindness in adults (1). miRNA, which exists in nematodes, drosophila, mammals, 

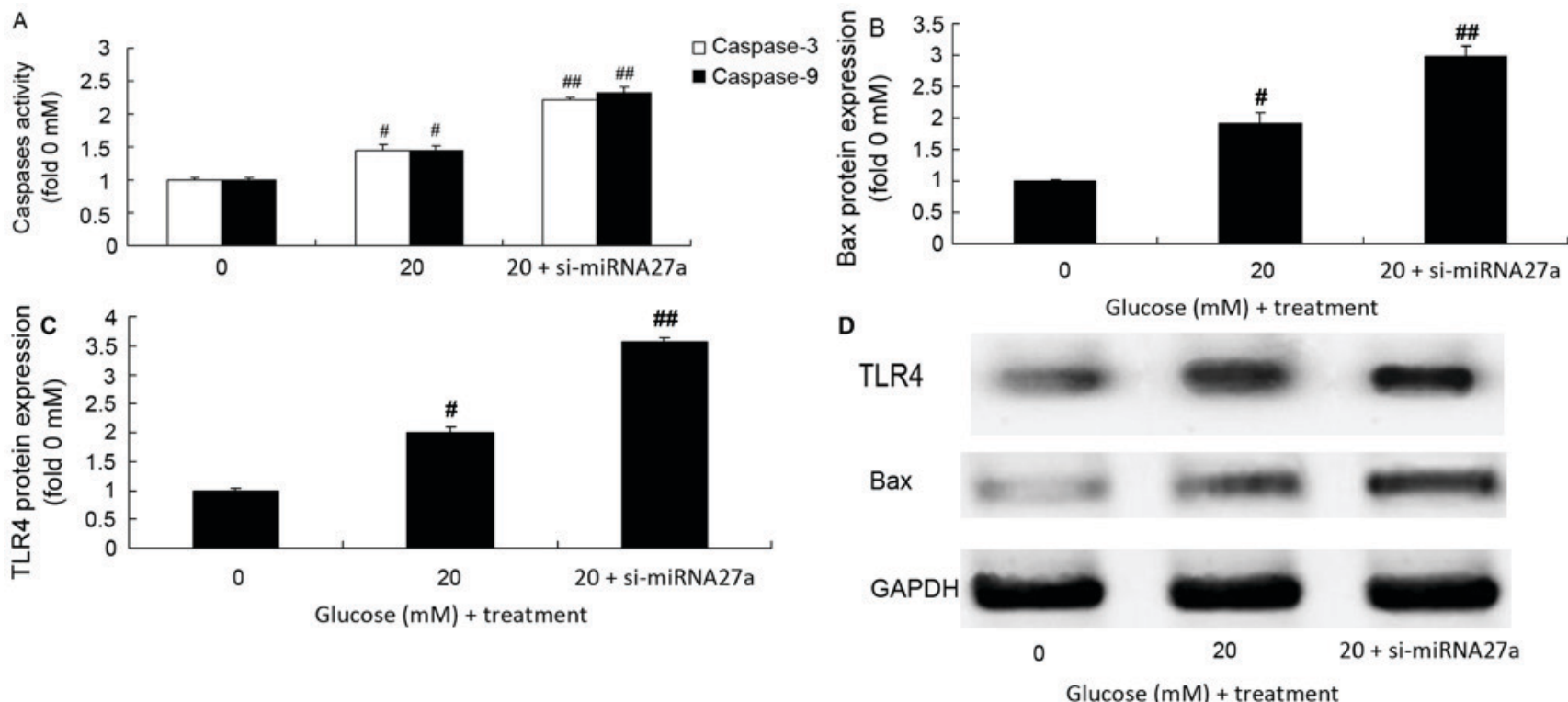

Figure 3. Inhibition of miRNA27a increases the caspase-3/9 activity, and Bax and TLR4 protein expression of retinal pigment epithelial cells subjected to high glucose concentrations. Inhibition of mRNA27a expression increased (A) caspase-3/9 activity, (B) Bax and (C) TLR4 protein expression quantification and (D) western blotting. ${ }^{~} \mathrm{P}<0.01$ vs. $0 \mathrm{mM}$ group; ${ }^{\# \prime} \mathrm{P}<0.01$ vs. $20 \mathrm{mM}$ group. Bax, B cell lymphoma 2-associated $\mathrm{X}$ protein; TLR4, Toll-like receptor 4; si, small interfering RNA; miRNA27a, microRNA-27a.

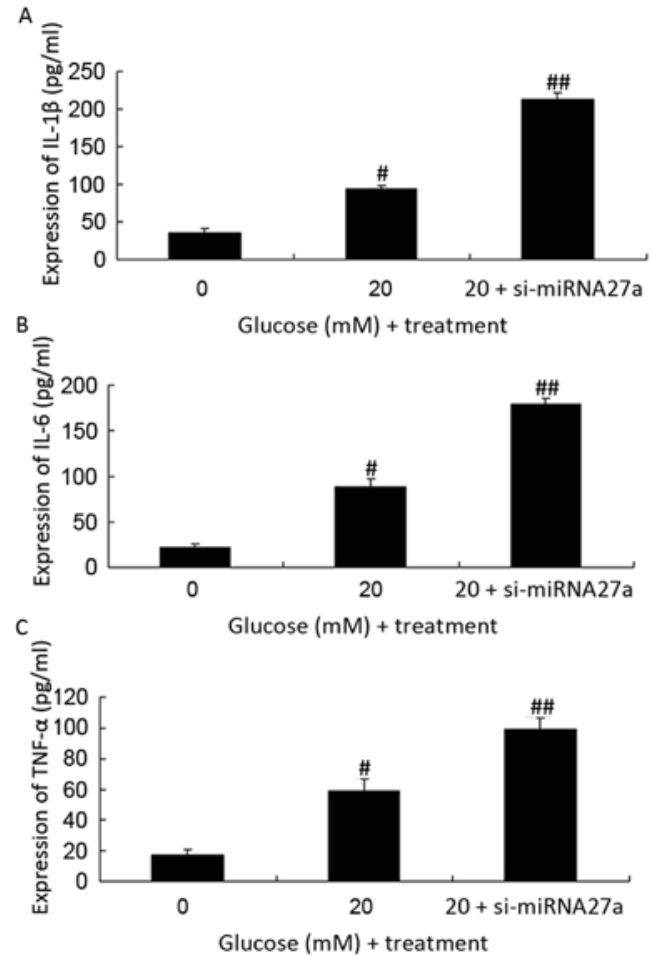

Figure 4. Inhibition of miRNA27a expression increases the expression of IL-1 $\beta$, IL-6 and TNF- $\alpha$ in retinal pigment epithelial cells subjected to high glucose concentrations. Inhibition of mRNA27a expression increased the expression of (A) IL-1 $\beta$, (B) IL- 6 and (C) TNF- $\alpha .{ }^{*} \mathrm{P}<0.01$ vs. $0 \mathrm{mM}$ group; ${ }^{\# \#} \mathrm{P}<0.01$ vs. $20 \mathrm{mM}$ group. si, small interfering RNA; miRNA27a, microRNA-27a; IL, interleukin; TNF, tumor necrosis factor.

plants and viruses, interacts with and inhibits the transcription of target mRNA molecules (15). miRNA genes are identified in the genome as single copies, multiple copies or gene clusters, the majority of which are located in intergenic regions (6). The transcription of miRNAs is independent of other genes and remains highly conserved throughout evolution. miRNA has spatial and temporal specificity (6). In addition, miRNA serves an important role in vital movements, such as transcription $(6,16)$. The results of the present study revealed that a high concentration of glucose was able to inhibit the expression of miRNA27a in RPE cells.

Previous studies from a number of institutions have revealed that diabetes may induce an increase in the expression of TLRs. A previous study demonstrated that the expression of TLR4 in the peripheral blood mononuclear cells of patients with diabetes was higher compared with those of individuals without diabetes (13). In addition, the expression of TLR4 is positively associated with the level of glycated hemoglobin, IL-1 $\beta$ and TNF- $\alpha$ (16). Another previous study demonstrated that the expression of TLR2 and TLR4 is increased in the peripheral blood mononuclear cells of patients with diabetes who also present with microvascular complications (17). Culturing these monocytes in vitro in a hyperglycemic state promoted the expression of TLR 2 and TLR4 in a time- and dose-dependent manner (18). In addition, the expression of TLR4 was demonstrated to be significantly increased in the adipose tissues of obese $\mathrm{db} / \mathrm{db}$ mice (18). Previous studies have revealed that the expression of TLR2 in the skeletal muscle and white fat of obese mice is increased $(13,19)$. The inhibition of TLR2 expression may suppress the activities of inhibitor of $N F-\kappa B$ subunit $\beta$ and mitogen-activated protein kinase 8 , indicating that TLR2 is a key regulator of inflammation and metabolism (18). It has also been demonstrated that in patients with type 2 diabetes the expression of TLR4 protein is associated with the severity of insulin resistance (18). The results of the present study indicated that the inhibition of miRNA27a increases TLR4 protein expression in RPE cells subjected to high glucose. Lv et al (20) suggested that miRNA27a is associated with the inflammatory response by targeting TLR4. 


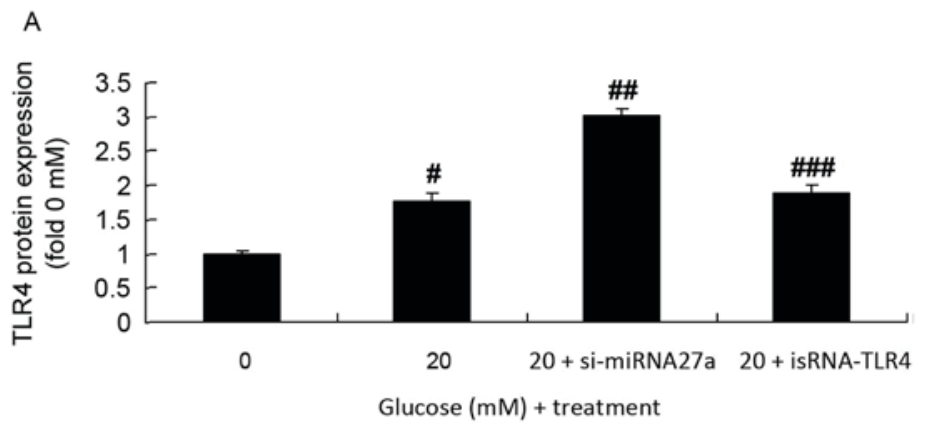

B
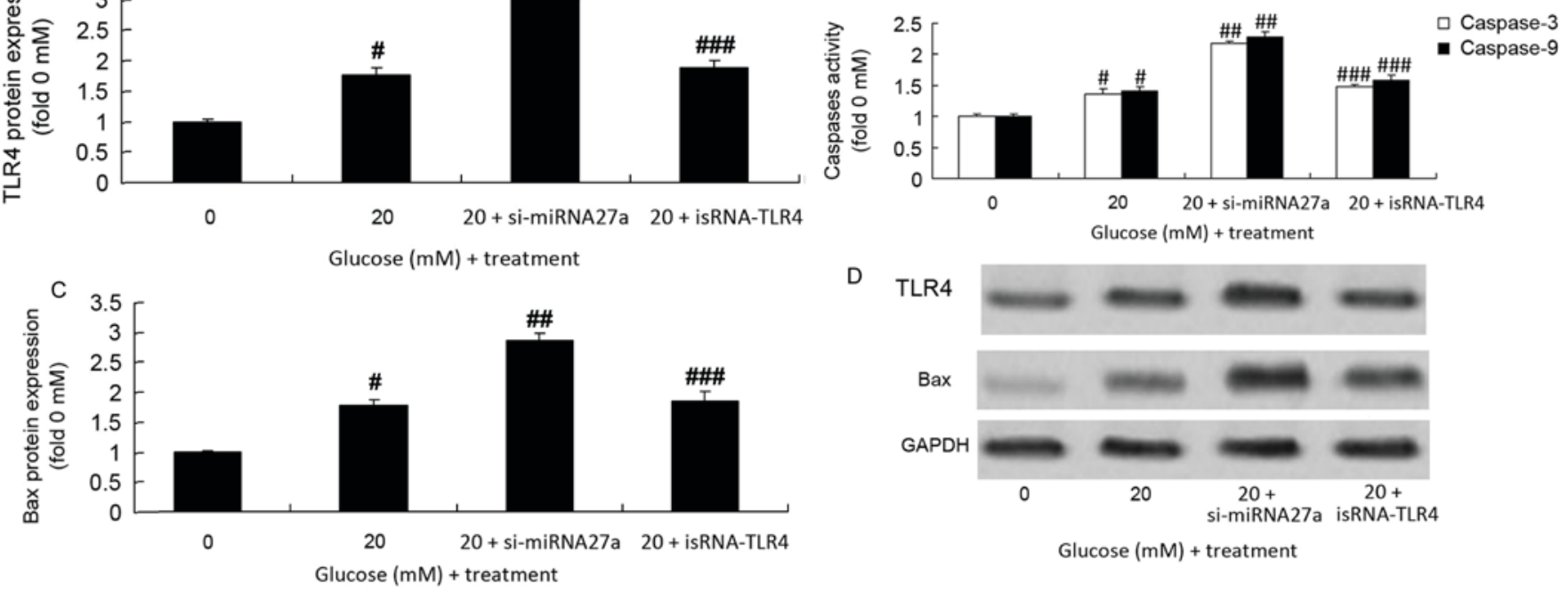

Glucose $(\mathrm{mM})+$ treatment

Figure 5. TLR4 expression is inhibited in si-miRNA27a-transfected retinal pigment epithelial cells subjected to high glucose following the transfection of isRNA-TLR4. (A) TLR4 protein expression, (B) caspase-3/9 activity and (C) Bax protein expression, quantification and (D) western blotting. " $\mathrm{P}<0.01$ vs. $0 \mathrm{mM}$ group; ${ }^{\# \#} \mathrm{P}<0.01$ vs. $20 \mathrm{mM}$ group; ${ }^{\# \# ~} \mathrm{P}<0.01$ vs. $20 \mathrm{mM}+$ si-mRNA27a group. TLR4, Toll-like receptor 4; si, small interfering RNA; miRNA27a, microRNA-27a; isRNA, immunostimulatory RNA.

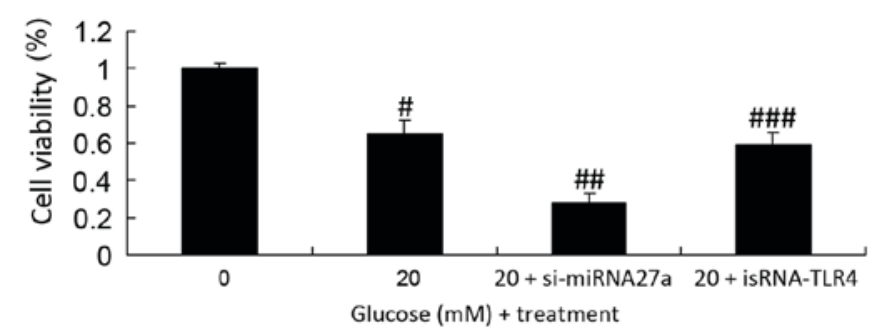

Figure 6. Inhibition of TLR4 increases the viability of si-miRNA27a-transfected retinal pigment epithelial cells subjected to high glucose. ${ }^{\#} \mathrm{P}<0.01$ vs. $0 \mathrm{mM}$ group; ${ }^{\#} \mathrm{P}<0.01$ vs. $20 \mathrm{mM}$ group; ${ }^{\# \#} \mathrm{P}<0.01$ vs. $20 \mathrm{mM}+$ si-mRNA27a group. TLR4, Toll-like receptor 4; si, small interfering RNA; miRNA27a, microRNA-27a; isRNA, immunostimulatory RNA.

The inflammatory response is a self-protective mechanism produced by the innate immune system when organisms are exposed to foreign antibodies or microorganisms (21). Molecules produced by pathogens are recognized by pattern recognition receptors, which stimulates the generation of TNF- $\alpha$ and IL-1 $\beta$, and proinflammatory proteins, including cyclooxygenase-2 and inducible nitric oxide synthase (1). Animal models of early stage DR demonstrate the production of these proteins, which may function to prevent the progression of retinopathy (22). The results of the present study indicated that inhibition of miRNA27a increases the expression of IL-6, IL- $1 \beta$ and TNF- $\alpha$ in RPE cells subjected to high glucose. Inhibition of TLR4 was demonstrated to decrease the expression of IL- 6 , IL- $1 \beta$ and TNF- $\alpha$ in si-miRNA27a-transfected RPE cells subjected to high glucose. Jennewein et al (23) reported that miRNA27b contributes to the progression of lipopolysaccharide-associated inflammatory diseases. The inhibition of miRNA-27a in RPE cells subjected to high glucose has an effect on
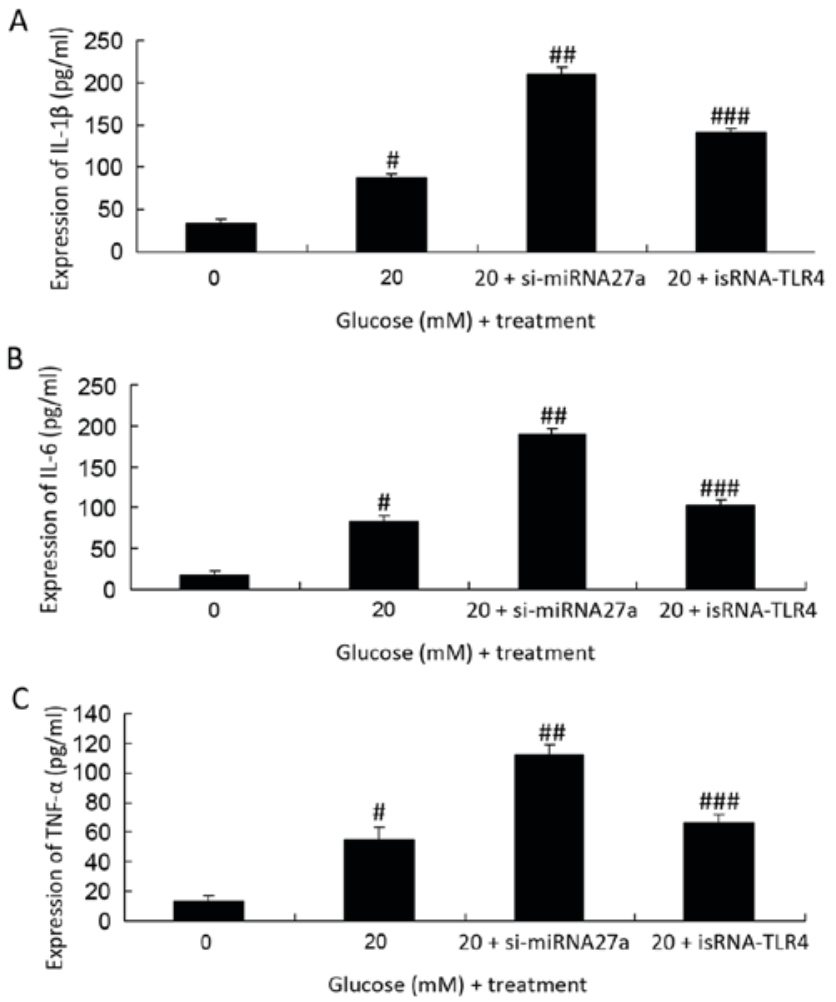

Figure 7. Inhibition of TLR4 decreases the expression of IL-6, IL-1 $\beta$ and TNF- $\alpha$ in miRNA27a-transfected retinal pigment epithelial cells subjected to high glucose. The effect of TLR4 inhibition on the expression of (A) IL-1 $\beta$, (B) IL-6 and (C) TNF- $\alpha .{ }^{~} \mathrm{P}<0.01$ vs. $0 \mathrm{mM}$ group; ${ }^{\# \#} \mathrm{P}<0.01$ vs. $20 \mathrm{mM}$ group;

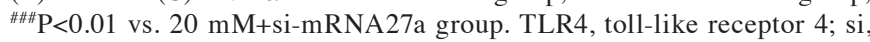
small interfering RNA; miRNA27a, microRNA-27a; IL, interleukin; TNF, tumor necrosis factor; isRNA, immunostimulatory RNA.

inflammation and apoptosis, suggesting that the level of miRNA-27a may be used as a biomarker for DR. 
DR, the most common and severe complication of diabetes, is a major cause of blindness in developed countries (24). A previous study revealed that in the early stage of diabetes, patients present with retinal microangiopathy and inhibited neuronal function, which are associated with apoptosis (25). A previous study investigating the expression of apoptotic markers indicated that the expression of certain markers, including caspase-3, fatty acid synthase (Fas) and Bax, was significantly increased in patients with diabetes compared with individuals without diabetes (26). In patients with diabetes, retinal ganglion cells that express caspase-3, Fas and Bax indicate cytoplasmic immunoreactivity. The apoptosis of pericytes results in the destruction of the retinal barrier and the apoptosis of retinal ganglion cells leads to decreasing visual function (27). Genes associated with apoptosis are members of the Bax protein family (28). In the present study, inhibition of miRNA27a was demonstrated to reduce the viability, and increase the caspase-3/9 activity and Bax protein expression of RPE cells subjected to high glucose. Tian et al (29) demonstrated that miRNA27a promotes the proliferation and suppresses the apoptosis of laryngeal carcinomas. These results suggest that the inhibition of miRNA27a has a protective effect on the high glucose-induced apoptosis of human RPE cells.

The results of the present study demonstrated that the inhibition of miRNA27a reduced the viability, and increased the caspase-3/9 activity and Bax protein expression of RPE cells subjected to high glucose concentrations through suppression of inflammation by targeting TLR4. In conclusion, the present study provides a useful insight into the role of mRNA27a in the regulation of high glucose-induced apoptosis and inflammatory mediators in DR.

\section{Acknowledgements}

Not applicable.

\section{Funding}

No funding was received.

\section{Availability of data and materials}

The datasets used and/or analyzed during the current study are available from the corresponding author on reasonable request.

\section{Authors' contributions}

XT, XW, JZ and GL designed the research study. YD performed the research. YD and XT analyzed the data. YD wrote the paper.

\section{Ethics approval and consent to participate}

Not applicable.

\section{Consent for publication}

Not applicable.

\section{Competing interests}

The authors declare that they have no competing interests.

\section{References}

1. Jeon S and Lee WK: Intravitreal bevacizumab increases intraocular interleukin-6 levels at 1 day after injection in patients with proliferative diabetic retinopathy. Cytokine 60: 535-539, 2012.

2. Ambresin A, Strueven V and Pournaras JA: Painless indirect argon laser in high risk proliferative diabetic retinopathy. Klin Monbl Augenheilkd 232: 509-513, 2015

3. Ribeiro L, Bandello F, Tejerina AN, Vujosevic S, Varano M, Egan C, Sivaprasad S, Menon G, Massin P, Verbraak FD, et al: Characterization of retinal disease progression in a 1-year longitudinal study of eyes with mild nonproliferative retinopathy in diabetes type 2. Invest Ophthalmol Vis Sci 56: 5698-5705, 2015.

4. Mansberger SL, Sheppler C, Barker G, Gardiner SK, Demirel S, Wooten $\mathrm{K}$ and Becker TM: Long-term comparative effectiveness of telemedicine in providing diabetic retinopathy screening examinations: A randomized clinical trial. JAMA Ophthalmol 133: 518-525, 2015.

5. Qing S, Yuan S, Yun C, Hui H, Mao P, Wen F, Ding Y and Liu Q: Serum miRNA biomarkers serve as a fingerprint for proliferative diabetic retinopathy. Cell Physiol Biochem 34: 1733-1740, 2014.

6. Zampetaki A, Willeit P, Burr S, Yin X, Langley SR, Kiechl S, Klein R, Rossing P, Chaturvedi N and Mayr M: Angiogenic microRNAs linked to incidence and progression of diabetic retinopathy in type 1 diabetes. Diabetes 65: 216-227, 2016.

7. Mohamed QA, Fletcher EC and Buckle M: Diabetic retinopathy: Intravitreal vascular endothelial growth factor inhibitors for diabetic macular oedema. BMJ Clin Evid 2016: pii: 0702, 2016.

8. Scott IU, Jackson GR, Quillen DA, Larsen M, Klein R, Liao J, Holfort S, Munch IC and Gardner TW: Effect of doxycycline vs placebo on retinal function and diabetic retinopathy progression in patients with severe nonproliferative or non-high-risk proliferative diabetic retinopathy: A randomized clinical trial. JAMA Ophthalmol 132: 535-543, 2014.

9. Kaštelan S, Tomić M, Gverović Antunica A, Salopek Rabatić J and Ljubić S: Inflammation and pharmacological treatment in diabetic retinopathy. Mediators Inflamm 2013: 213130, 2013.

10. Chen ZH, Wu YF, Wang PL, Wu YP, Li ZY, Zhao Y, Zhou JS, Zhu C, Cao C, Mao YY, et al: Autophagy is essential for ultrafine particle-induced inflammation and mucus hyperproduction in airway epithelium. Autophagy 12: 297-311, 2016.

11. Qin WD, Liu GL, Wang J, Wang H, Zhang JN, Zhang F, Ma Y Ji XY, Li C and Zhang MX: Poly(ADP-ribose) polymerase 1 inhibition protects cardiomyocytes from inflammation and apoptosis in diabetic cardiomyopathy. Oncotarget 7: 35618-35631, 2016.

12. Zhang X, Sun CY, Zhang YB, Guo HZ, Feng XX, Peng SZ, Yuan J, Zheng RB, Chen WP, Su ZR and Huang XD: Kegan Liyan oral liquid ameliorates lipopolysaccharide-induced acute lung injury through inhibition of TLR4-mediated NF- $\mathrm{NB}$ signaling pathway and MMP-9 expression. J Ethnopharmacol 186: 91-102, 2016.

13. Singh K, Kant S, Singh VK, Agrawal NK, Gupta SK and Singh K: Toll-like receptor 4 polymorphisms and their haplotypes modulate the risk of developing diabetic retinopathy in type 2 diabetes patients. Mol Vis 20: 704-713, 2014.

14. Livak KJ and Schmittgen TD: Analysis of relative gene expression data using real-time quantitative PCR and the 2(-Delta Delta C(T)) method. Methods 25: 402-408, 2001.

15. Bressler SB, Almukhtar T, Aiello LP, Bressler NM, Ferris FL III, Glassman AR and Greven CM; Diabetic Retinopathy Clinical Research Network: Green or yellow laser treatment for diabetic macular edema: Exploratory assessment within the diabetic retinopathy clinical research network. Retina 33: 2080-2088, 2013.

16. Lin WJ and Yeh WC: Implication of Toll-like receptor and tumor necrosis factor alpha signaling in septic shock. Shock 24: 206-209, 2005

17. Chen XL, Zhang XD, Li YY, Chen XM, Tang DR and Ran RJ: Involvement of HMGB1 mediated signalling pathway in diabetic retinopathy: Evidence from type 2 diabetic rats and ARPE-19 cells under diabetic condition. Br J Ophthalmol 97: 1598-1603, 2013.

18. Rajamani U and Jialal I: Hyperglycemia induces Toll-like receptor- 2 and -4 expression and activity in human microvascular retinal endothelial cells: Implications for diabetic retinopathy. J Diabetes Res 2014: 790902, 2014. 
19. Berger EA, Carion TW, Jiang Y, Liu L, Chahine A, Walker RJ and Steinle JJ: $\beta$-Adrenergic receptor agonist, compound 49b, inhibits TLR4 signaling pathway in diabetic retina. Immunol Cell Biol 94: 656-661, 2016.

20. Lv YN, Ou-Yang AJ and Fu LS: MicroRNA-27a negatively modulates the inflammatory response in lipopolysaccharide-stimulated microglia by targeting TLR4 and IRAK4. Cell Mol Neurobiol 37: 195-210, 2017.

21. $\mathrm{Xu} \mathrm{H}$ and Chen $\mathrm{M}$ : Targeting the complement system for the management of retinal inflammatory and degenerative diseases. Eur J Pharmacol 787: 94-104, 2016.

22. Wohlfart P, Lin J, Dietrich N, Kannt A, Elvert R, Herling AW and Hammes HP: Expression patterning reveals retinal inflammation as a minor factor in experimental retinopathy of ZDF rats. Acta Diabetol 51: 553-558, 2014.

23. Jennewein C, von Knethen A, Schmid T and Brune B MicroRNA-27b contributes to lipopolysaccharide-mediated peroxisome proliferator-activated receptor gamma (PPARgamma) mRNA destabilization. J Biol Chem 285: 11846-11853, 2010.

24. Dong Z, Tao X, Fu X, Wang H, Wang D and Zhang T: Protective effects of Purendan superfine powder on retinal neuron apoptosis in a rat model of type 2 diabetes mellitus. Neural Regen Res 7: 202-206, 2012.
25. Kowluru RA: Diabetic retinopathy: Mitochondrial dysfunction and retinal capillary cell death. Antioxid Redox Signal 7: 1581-1587, 2005.

26. Khalfaoui T, Basora N and Ouertani-Meddeb A: Apoptotic factors (Bcl-2 and Bax) and diabetic retinopathy in type 2 diabetes. J Mol Histol 41: 143-152, 2010.

27. Kern TS, Du Y, Miller CM, Hatala DA and Levin LA: Overexpression of $\mathrm{Bcl}-2$ in vascular endothelium inhibits the microvascular lesions of diabetic retinopathy. Am J Pathol 176: 2550-2558, 2010.

28. Fan Y, Liu K, Wang Q, Ruan Y, Zhang Y and Ye W: Exendin-4 protects retinal cells from early diabetes in Goto-Kakizaki rats by increasing the $\mathrm{Bcl}-2 / \mathrm{Bax}$ and $\mathrm{Bcl}-\mathrm{xL} / \mathrm{Bax}$ ratios and reducing reactive gliosis. Mol Vis 20: 1557-1568, 2014.

29. Tian Y, Fu S, Qiu GB, Xu ZM, Liu N, Zhang XW, Chen S, Wang Y, Sun KL and Fu WN: MicroRNA-27a promotes proliferation and suppresses apoptosis by targeting PLK2 in laryngeal carcinoma. BMC Cancer 14: 678, 2014. 